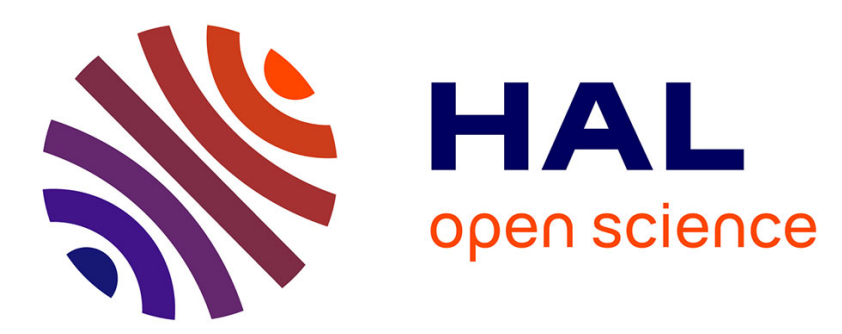

\title{
Kinetic and thermodynamic aspects of the electrocatalysis of acid reduction in organic solvent using molecular diiron-dithiolate compounds
}

Francois Quentel, Frederic Gloaguen

\section{To cite this version:}

Francois Quentel, Frederic Gloaguen. Kinetic and thermodynamic aspects of the electrocatalysis of acid reduction in organic solvent using molecular diiron-dithiolate compounds. 2015. hal-01130667

\section{HAL Id: hal-01130667 \\ https://hal.univ-brest.fr/hal-01130667}

Preprint submitted on 12 Mar 2015

HAL is a multi-disciplinary open access archive for the deposit and dissemination of scientific research documents, whether they are published or not. The documents may come from teaching and research institutions in France or abroad, or from public or private research centers.
L'archive ouverte pluridisciplinaire HAL, est destinée au dépôt et à la diffusion de documents scientifiques de niveau recherche, publiés ou non, émanant des établissements d'enseignement et de recherche français ou étrangers, des laboratoires publics ou privés. 
NOTICE: This is the author's version of a work accepted for publication by Elsevier.

Changes resulting from the publishing process, including peer review, editing, corrections, structural formatting and other quality control mechanisms, may not be reflected in this document. Changes may have been made to this work since it was submitted for publication. A subsequent version will be published in ELECTOCHIMICA ACTA and will be available at http://dx.doi.org/10.1016/j.electacta.2013.05.048

\title{
Kinetic and thermodynamic aspects of the electrocatalysis of acid reduction in organic solvent using molecular diiron-dithiolate compounds
}

François Quentel and Frederic Gloaguen*

UMR 6521, CNRS, Université de Bretagne Occidentale, 6 Avenue Le Gorgeu, 29238 Brest, France.

E-mail address:fgloague@univ-brest.fr

\begin{abstract}
In an attempt to obtain molecular $\mathrm{H}_{2}$ production electrocatalysts achieving balanced basicity and reduction potential, we focused on the mono-substituted diiron-dithiolate derivative $\left[\mathrm{Fe}_{2}(\mu-\mathrm{bdt})(\mathrm{CO})_{5}\left(\mathrm{P}(\mathrm{OMe})_{3}\right)\right](\mathrm{bdt}=$ benzenedithiolate $)$. The electrocatalytic efficiency of this iron-iron hydrogenase model was determined by cyclic voltammetry in acetonitrile using $p$ toluenesulfonic acid as a proton source. Detailed analysis of the current - potential responses and comparison with the all-CO diiron-dithiolate parent compound clearly show that the effect of the chemical properties on the electrocatalytic efficiency is not fully determined by the turnover frequency under pseudo-first-order approximation and the overpotential defined as the difference between the reduction potential of the electrocatalysts in the absence of acid and the reversible potential of the couple $\mathrm{H}_{2}$ /acid.
\end{abstract}

\section{Keywords}


hydrogen production; hydrogenase model; molecular electrocatalyst; overpotential; turnover frequency

\section{Introduction}

The electrochemical reduction of a proton source to produce dihydrogen $\left(\mathrm{H}_{2}\right)$ is a reaction of both fundamental and economic significance [1-3]. Electrocatalysis of this reaction can be achieved homogeneously via protonation and electrochemical (or photochemical) reduction of a suitable Brønsted base in solution [4, 5]. Advances in this area have afforded molecular electrocatalysts that employ cobalt, molybdenum, nickel, or iron [611], instead of platinum that is currently the preferred electrocatalyst for proton reduction in water [12].

Given the interest of developing $\mathrm{H}_{2}$-production electrocatalysts based on cheap and abundant materials, synthetic models of the iron-iron hydrogenase enzymes have been the subject of numerous studies[13-18]. Diiron-dithiolate compounds of the type $\left[\mathrm{Fe}_{2}(\mu-\right.$ $\left.\mathrm{SRS})(\mathrm{CO})_{6-\mathrm{x}} \mathrm{L}_{\mathrm{x}}\right](\mathrm{R}=$ organic group, $\mathrm{L}=$ electron-donor ligand, $\mathrm{x} \leq 4)$ have been shown to electrocatalyze the reduction of acid in organic solvents [19-21] and, very recently, in aqueous micellar solutions $[22,23]$ (for examples of photo-driven $\mathrm{H}_{2}$-production by diiron-dithiolate compounds see $[24,25])$. The electrocatalytic pathway entails successive electron and proton transfers in a sequence that depends on the nature of the terminal ligand $\mathrm{L}$ and the strength of the acid used as proton source $[16,26]$. The key intermediate is a putative $\mathrm{Fe}^{0} \mathrm{Fe}^{\mathrm{II}} \mathrm{H}$ hydride the reactivity of which controls the thermodynamic and kinetic aspects of the electrocatalytic process. Production of $\mathrm{H}_{2}$ can occur by reaction of $\mathrm{Fe}^{0} \mathrm{Fe}^{\mathrm{II}} \mathrm{H}$ with protons or bimolecular 
combination of two $\mathrm{Fe}^{0} \mathrm{Fe}^{\mathrm{II}} \mathrm{H}$. Alternatively, $\mathrm{Fe}^{0} \mathrm{Fe}^{\mathrm{II}} \mathrm{H}$ can be further reduced leading to $\mathrm{Fe}^{0} \mathrm{Fe}^{\mathrm{I}} \mathrm{H}$, which can similarly follows heterolytic or homolytic pathways to generate $\mathrm{H}_{2}$. We [27-32], and others [33-37], have previously shown that the use of rigid and unsaturated bridging ligands lowers the reduction potential of the diiron-dithiolate compounds and increases the stability of their reduced forms. This approach is well illustrated by the diiron-benzenedithiolate derivative $\left[\mathrm{Fe}_{2}(\mu-\mathrm{bdt})(\mathrm{CO})_{6}\right](\mathbf{1}$, Scheme 1) that electrocatalyzes the reduction of strong acids in organic solvent at the mild potential of $-1.3 \mathrm{~V} v s .^{\mathrm{F}} \mathrm{F}^{+/ 0}[27,28]$. However, the delocalization of the electron density into the bdt-bridging ligand also decreases the basicity of the diiron center, which is the proton activation site, and therefore slows down the overall electrocatalytic process. The two-electron one-proton intermediate $1 \mathrm{H}$ - must hence be further reduced to produce $\mathrm{H}_{2}$ at an appreciable rate, but with a large thermodynamic cost of about $0.8 \mathrm{~V}$ [33]. In an attempt to obtain diiron-dithiolate electrocatalysts achieving balanced basicity and reduction potential, we focused on the mono-substituted derivative $\left[\mathrm{Fe}_{2}(\mu-\mathrm{bdt})(\mathrm{CO})_{5}\left(\mathrm{P}(\mathrm{OMe})_{3}\right)\right](\mathbf{2}$, Scheme 1) [29].

The activity of a molecular electrocatalyst for proton reduction is usually characterized by its overpotential and its turnover frequency. The overpotential is defined as the difference between the reduction potential of the molecular electrocatalysts in the absence of acid and the reversible potential of the couple $\mathrm{H}_{2}$ /acid in the solvent used for the electrochemical measurements. Under pseudo-first-order conditions (i.e. negligible acid consumption in the vicinity of the electrode over the course of the electrochemical measurements), the turnover frequency is equal to the rate constant $\left(k_{\mathrm{cat}}\right.$ in $\left.\mathrm{s}^{-1}\right)$ of the catalytic step $\mathrm{C}_{\mathrm{cat}}$. When the catalytic process entails a reversible electron-transfer step followed by a catalytic step (i.e. an $\mathrm{EC}_{\mathrm{cat}}$ scheme), which is the case for 1 and 2 in the presence of HOTs, the turnover frequency $k_{\text {cat }}$ can be estimated from the intensity of the catalytic current measured by cyclic voltammetry. Another useful parameter is the turnover number, which is defined here as number of cycles 
achieved by the molecular electrocatalyst without noticeable deactivation. The turnover number is calculated from bulk electrolysis experiments.

In this report, we present a detailed electrochemical study of $\mathbf{2}$ in solution in acetonitrile in the presence of $p$-toluenesulfonic acid (HOTs, $\left.\mathrm{p} K_{\mathrm{a}}=8.7\right)$ as a proton source. The electrocatalytic efficiency, in terms of turnover frequency and overpotential, of 2 for the reduction of HOTs is compared to that of $\mathbf{1}$, and the effect of replacing one $\mathrm{CO}$ by one $\mathrm{P}(\mathrm{OMe})_{3}$ ligand is discussed.

\section{Experimental}

$\left[\mathrm{Fe}_{2}(\mu-\mathrm{bdt})(\mathrm{CO})_{6}\right](\mathbf{1})$ and $\left[\mathrm{Fe}_{2}(\mu-\mathrm{bdt})(\mathrm{CO})_{5}\left(\mathrm{P}(\mathrm{OMe})_{3}\right)\right](2)$ were prepared according to previously published procedures and characterized by elemental analysis, and IR and ${ }^{1} \mathrm{H}$ NMR spectroscopy $[23,35]$. Tetrabutylammonium hexafluorophosphate $\left(\mathrm{Bu}_{4} \mathrm{NPF}_{6}\right)$ was purified by crystallization. Acetonitrile (MeCN, HPLC-grade) and $p$-toluenesulfonic acid monohydrate $\left(\mathrm{HOTs}, \mathrm{p} K_{\mathrm{a}}=8.7\right)$ were used as received. The cyclic voltammetry $(\mathrm{CV})$ experiments were carried out in $\mathrm{N}_{2}$-purged $\mathrm{Bu}_{4} \mathrm{NPF}_{6} / \mathrm{MeCN}$ solutions. The working electrode was a glassy carbon (GC) electrode of $0.071 \mathrm{~cm}^{2}$ carefully polished with alumina paste prior to all experiments. Special attention was put on minimization of the ohmic drop by using diluted solutions of diiron-dithiolate compounds $(\leq 0.5 \mathrm{mM})$ and by placing the tip of the reference electrode as close as possible to the GC disk used as working electrode. The uncompensated solution resistance was $R_{\mathrm{u}} \sim 130 \Omega$. The proton concentration was varied by addition of small volumes of concentrated acid solution in MeCN. Controlled potential electrolysis (CPE) experiments were carried in $\mathrm{N}_{2}$-purged $\mathrm{Bu}_{4} \mathrm{NPF}_{6} / \mathrm{MeCN}$ solutions using a stirred mercury pool electrode of about $3.2 \mathrm{~cm}^{2}$. The presence of $\mathrm{H}_{2}$ in the electrolysis cell headspace was confirmed by gas chromatography analysis [22]. 


\section{Results and Discussion}

\section{1. $C V$ experiments in the absence of acid}

The reversible reduction of 2 at a GC electrode in $\mathrm{Bu}_{4} \mathrm{NPF}_{6} / \mathrm{MeCN}$ occurs at $E_{1 / 2}=$ $-1.51 \mathrm{~V}$ (all electrode potentials are reported relative to that of the $\mathrm{Fc} / \mathrm{Fc}^{+}$couple used as an internal reference). Under otherwise similar conditions, the reversible reduction of 1 occurs at $E_{1 / 2}=-1.28 \mathrm{~V}$. The negative shift of $0.23 \mathrm{~V}$ observed upon replacement of one $\mathrm{CO}$ by one $\mathrm{P}(\mathrm{OMe})_{3}$ ligand is consistent with the potential shifts reported for other diiron-dithiolate compounds [38]. It is reasonable to assume that these effect is due to the more electron donor ability of $\mathrm{P}(\mathrm{OMe})_{3}$ ligand as compared to that of carbonyl ligand.

The normalized $\mathrm{CV}$ of $\mathbf{2}$ clearly show a continuous transition from a one-electron to a two-electron process as the scan rate $v$ is slowed down (Fig. 1) [39]. The two-electron process observed at $v \leq 2 \mathrm{~V} \mathrm{~s}^{-1}$ is ascribed to a potential inversion, and suggests that 2 undergoes a large structural rearrangements, as seen for 1- [33]. In contrast, the PTA-substituted derivatives $(\mathrm{PTA}=1,3,5$-triaza-7-phosphaadamentane) have been reported to only undergo a one-electron reduction [35]. This discrepancy can be explained by the comparatively low steric hindrance of the $\mathrm{P}(\mathrm{OMe})_{3}$ ligand, which does not impede the rotation of the $\mathrm{Fe}(\mathrm{CO})_{3}$ unit in $\mathbf{2}$, and therefore the geometric rearrangement necessary for an initial two-electron reduction.

\section{2. $C V$ and $C P E$ experiments in the presence of p-toluenesulfonic acid}


We have previously shown that the electrocatalytic reduction of acid by $\mathbf{2}$ might follow an initial CE scheme, in which the slow reaction of $\mathbf{2}$ with strong acid is driven in the vicinity of the electrode by the reduction of $2 \mathrm{H}^{+}$at a potential less negative than that of 2 [29]. Here the CV measurements were carried out at fast scan rates $\left(v \geq 0.5 \mathrm{~V} \mathrm{~s}^{-1}\right)$ to limit the incidence of this reaction pathway.

Usually the overpotential $(\eta)$ for the electrocatalytic $\mathrm{H}_{2}$ production is defined as the difference between the reduction potential of the electrocatalysts in the absence of acid and the reversible potential of the couple $\mathrm{H}_{2}$ /acid [40]. According to Evans and coworker [41], the potential of the couple $\mathrm{H}_{2} / \mathrm{HOT}$ s is about $-0.65 \mathrm{~V}$ in MeCN, which gives a value of $\eta=E_{1 / 2}-$ $E_{\mathrm{H} 2 / \mathrm{HOTS}}=-0.86 \mathrm{~V}$ for the $2 / \mathrm{MeCN}+\mathrm{HOTs}$ system. Similar calculation gives a value of overpotential $\eta=-0.63 \mathrm{~V}$ for the $\mathbf{1} / \mathrm{MeCN}+\mathrm{HOT}$ system.

Addition of $5.3 \mathrm{mmol} \mathrm{dm}^{3}$ of HOTs to a solution $0.46 \mathrm{mmol} \mathrm{dm}^{3} 2$ in $\mathrm{Bu}_{4} \mathrm{NPF}_{6} / \mathrm{MeCN}$ results in a large current increase at a potential slightly less negative than that of the couple $2 / 2^{2}-\left(E_{\mathrm{p} / 2}=-1.46 \mathrm{~V}\right.$ at $v=0.5 \mathrm{~V} \mathrm{~s}^{-}{ }^{1}$, Fig. 2). Since no significant reduction current was observed in this potential range for a solution that contains only $5 \mathrm{mM}$ HOTs, the electrochemical response is consistent with an electrocatalytic reduction of HOTs mediated by the reduction of 2 .

The production of $\mathrm{H}_{2}$ upon electrocatalytic reduction of $50 \mathrm{mmol} \mathrm{dm}^{3} \mathrm{HOTs}$ in the presence of $0.6 \mathrm{mmol} \mathrm{dm}{ }^{3} 2$ was confirmed by CPE experiment at $-1.5 \mathrm{~V}$. Initially, the charge passed increases linearly with time reaching a value of $21 \mathrm{C}$ after $50 \mathrm{~min}$, which corresponds to a value of turnover number of 31 for a Faradaic efficiency of $100 \%$. After a period of electrolysis of about one hour, the charge $v s$. time plot level off, indicative of a deactivation of the electrocatalyst. A similar value of turnover number was achieved by $\mathbf{1}$ at 1.3 $\mathrm{V}$ before deactivation. Note that observation of $\mathrm{H}_{2}$ production at a mercury pool electrode 
clearly establishes that the true electrocatalyst is a molecular species and not metal-particles coming from the reduction of the diiron-dithiolate compounds [42, 43].

From these results and on the basis of literature precedents [28, 29], we propose the electrocatalytic mechanism depicted in Scheme 2. Compound $\mathbf{2}$ is first reduced and protonated (i.e. oxidative addition of $\mathrm{H}^{+}$) to rapidly give $\mathrm{Fe}^{0} \mathrm{Fe}^{\mathrm{II}} \mathrm{H}$. Whether this transient hydride is formed via an EEC or an ECE pathway is not established. Since $\mathrm{Fe}^{0} \mathrm{Fe}^{\mathrm{II}} \mathrm{H}$ is a significantly weaker base than $\mathrm{Fe}^{0} \mathrm{Fe}^{0}$ (or $\mathrm{Fe}^{\mathrm{I}} \mathrm{Fe}^{0}$ ), we assume that the rate-determining step is the coupling of the transient hydride with an additional proton to release $\mathrm{H}_{2}$. This reaction pathway is equivalent to an $\mathrm{EC}_{\mathrm{cat}}$ mechanism, in which the chemical step $\mathrm{C}_{\mathrm{cat}}$ is the ratedetermining step [44, 45].

As shown in Fig. 2, a plot of the ratio of the catalytic current $\left(I_{\text {cat }}\right)$ to the peak current in the absence of acid $\left(I_{\mathrm{p}}\right)$ as a function of the concentration of HOTs exhibits a plateau-like behavior at $[$ HOTs $]>5 \mathrm{mmol} \mathrm{dm}^{3}$, where it reaches a maximum value of $I_{\text {cat }} / I_{\mathrm{p}}=4.8$ (Fig. 2). Under otherwise similar conditions, we measured a maximum current enhancement $I_{\text {cat }} / I_{\mathrm{p}}=$ 2.6 with 1 . According to DuBois and coworkers [46], the maximum value of current enhancement $I_{\text {cat }} / I_{\mathrm{p}}$ measured in the acid-independent region (i.e. pseudo-first-order approximation) can be related to the turnover frequency $k_{\mathrm{cat}}\left(\mathrm{s}^{-1}\right)$ of the electrocatalyst by the following equation:

$$
I_{\text {cat }} / I_{\mathrm{p}}=2.24 \times n\left(R T k_{\mathrm{cat}} / F v\right)^{1 / 2}
$$

where $n(=2)$ is the number of electron involved in the reduction of the acid, $R$ the gas constant, $T(=293 \mathrm{~K})$ the temperature, and $F\left(=96500 \mathrm{C} \mathrm{mol}^{1}\right)$ the Faraday constant. Using the experimentally determined values of $I_{\text {cat }} / I_{\mathrm{p}}$, we calculated $k_{\text {cat }}=23$ and $7 \mathrm{~s}^{-1}$ for $\mathbf{2}$ and $\mathbf{1}$, respectively. Thus, $\mathbf{2}$ achieves a larger turnover frequency than $\mathbf{1}$ in the presence of HOTs as proton source, but we still do not know whether this result is related to a difference in chemical reactivity $\left(\mathrm{P}(\mathrm{OMe})_{3} v s . \mathrm{CO}\right)$ or to a larger overpotential $(\eta=-0.86 \mathrm{~V}$ for 2 vs. -0.63 
V for 1). In addition, it is to be stressed that Eq. (1) can only be employed for estimating the turnover frequency in the limit of high acid concentration [46], which is obviously not the case here.

\subsection{Foot-of-the-wave analysis of the $C V$ under electrocatalytic conditions}

In principle, the use of Eq. (1) to calculate the turnover frequency of the electrocatalyst under scrutiny is restricted to situations where a well-defined S-shaped electrocatalytic wave is obtained. In our system, like for most of the molecular $\mathrm{H}_{2}$-production electrocatalysts (see e.g. $[40,47,48])$, we recorded peak-shaped electrocatalytic responses exhibiting current hysteresis between the forward and the return scan (Fig. 2). We also note that the value of $I_{\text {cat }}$ increases with the scan rate for $v \geq 0.5 \mathrm{~V} \mathrm{~s}^{-1}$ (Fig. 2). Since the flux of acid is proportional to the product $\left[\mathrm{HOT}_{\mathrm{S}}\right] \times v^{1 / 2}$, an increase of $I_{\text {cat }}$ with $v$ means that the electrode reaction is only under partial control of the electrocatalytic cycle (i.e. the pure kinetic region is not reached [49]). This observation might be here indicative of non-negligible consumption of the acid in the course of the $\mathrm{CV}$ experiment, but also of deactivation of the electrocatalyst and/or inhibition by reaction products. All these side-phenomena can interfere, preventing achievement of the expected electrocatalytic current. Based on these considerations, Savéant and coworkers have recently proposed a new method to extract the turnover frequency from CV experiments recorded under electrocatalytic conditions [50]. This method consists in using Eq. (2), describing the $I v s . E$ response for pure electrocatalytic conditions, to analyze the foot of the CV wave, where currents are low and therefore less altered by the sidephenomena described above.

$$
I / I_{\mathrm{p}}=2.24 \times\left(R T k_{\mathrm{cat}} / F v\right)^{1 / 2} /\left(1+\exp \left(F\left(E-E_{1 / 2}\right) / R T\right)\right)
$$


Accordingly, the value of the turnover frequency $k_{\text {cat }}$ is directly calculated from the slope of the linear portion of a plot of $I / I_{\mathrm{p}} v s .1 /\left(1+\exp \left(F\left(E-E_{1 / 2}\right) / R T\right)\right)$.

The foot-of-the-wave analysis of the $\mathrm{CV}$ at $0.5 \mathrm{~V} \mathrm{~s}^{-1}$ of $0.46 \mathrm{mmol} \mathrm{dm}^{3} 2$ in the presence of $5.3 \mathrm{mmol} \mathrm{dm}{ }^{3}$ HOTs is shown in Fig. 3. Deviation from linearity is observed for $I / I_{\mathrm{p}}>1.3$. From the slope of the linear portion, we calculated a value of $k_{\text {cat }}=2400 \mathrm{~s}^{-1}$. Values of $k_{\text {cat }}=2793$ and $2359 \mathrm{~s}^{-1}$ were derived from CV measured respectively at a scan rate of 0.2 and $1 \mathrm{~V} \mathrm{~s}^{-1}$, indicating that the turnover frequency of $\mathbf{2}$ can be estimated with a good precision using this method. The foot-of-the-wave analysis of the CV of a solution of $\mathbf{1}$ under similar experimental conditions $\left(v=0.5 \mathrm{~V} \mathrm{~s}^{-1},[\mathrm{HOTs}] /[1]=12\right)$ gives a value of $k_{\mathrm{cat}}=41 \mathrm{~s}^{-1}$ (Fig. 3$)$.

The values of $k_{\text {cat }}$ calculated using Eqs (1) and (2) under similar experimental conditions of both scan rate and acid concentration indicate both that $\mathbf{2}$ achieves a larger turnover frequency than 1. However, the values calculated using Eq. (1) appears to be underestimated by a factor of one hundred for $\mathbf{2}$ and only by a factor of six for $\mathbf{1}$. This results emphasizes the utility of the foot-of-the-wave analysis method, in particular when the acid concentration is low (vide infra).

The $\mathrm{EC}_{\text {cat }}$ mechanism discussed here implies that the pseudo-first-order rate constant $k_{\text {cat }}$ of the chemical step $\mathrm{C}_{\text {cat }}$ depends on the concentration of acid in solution [51]. In the present study, we cannot increase $\left[\mathrm{HOT}_{\mathrm{S}}\right]$ much above $5 \mathrm{mM}$, since then the contribution of direct acid reduction to the measured current would be no more negligible. The second-order rate constant $k=k_{\mathrm{cat}} /[\mathrm{HOTs}]\left(\mathrm{mol}^{1} \mathrm{dm}^{3} \mathrm{~s}^{1}\right)$ is therefore a more appropriate intrinsic measure of the electrocatalytic activity of $\mathbf{2}$. In addition, following the approach developed by Savéant and coworkers [50], we can relate the rate constant $k$ to the driving force $E-E_{\mathrm{H} 2 / \mathrm{HOTs}}$ for the electrocatalytic reaction, as follows:

$$
\log k=\log \left(k_{\mathrm{cat}} /[\mathrm{HOTs}]\right)-F\left(E_{\mathrm{H} 2 / \mathrm{HOTs}}-E_{1 / 2}\right) / 2.3 R T-\mathrm{F}\left(E-E_{\mathrm{H} 2 / \mathrm{HOTs}}\right) / 2.3 R T
$$


Now the question that arises is whether the larger apparent electrocatalytic activity of $\mathbf{2}$ is due to the increase of basicity of the diiron site, accelerating the rate-determining step (Scheme 2), or to a larger driving force for the reduction of HOTs. Using Eq. (3) and the values of $k_{\text {cat }}$ determined by the foot-of-the-wave analysis of the electrocatalytic responses of $\mathbf{2}$ and $\mathbf{1}$ (see Fig. 3), we obtained the plots of $\log k v s .\left(E-E_{\mathrm{H} 2 / \mathrm{HOTs}}\right)$ shown in Fig. 4. Extrapolation of these Tafel-like plots to zero driving force gives a measure of the intrinsic efficiency of the electrocatalyst/MeCN +HOTs system: $k_{0}=7.0 \times 10^{-10}$ and $9.3 \times 10^{-8} \mathrm{~mol}^{-1} \mathrm{dm}^{3} \mathrm{~s}^{-1}$ for $\mathbf{2}$ and $\mathbf{1}$, respectively. This result indicates that, despite achievement of a larger turnover frequency, 2 is intrinsically less efficient than $\mathbf{1}$ for the electrocatalytic reduction of HOTs. Of course using a weaker acid as a proton source (i.e. an acid HA exhibiting a value of $E_{\mathrm{H} 2 / \mathrm{HA}}$ closer to that of the reduction of 2) could have led to an opposite result.

\section{Conclusions}

The above analysis clearly show that the efficiency of a molecular $\mathrm{H}_{2}$-production electrocatalysts is not fully determined by its turnover frequency under pseudo-first-order approximation and its overpotential usually defined as the difference $E_{1 / 2}-E_{\mathrm{H} 2 / \mathrm{HA}}$. An optimization of the electrocatalytic efficiency for $\mathrm{H}_{2}$ production implies to adjust the chemical and electrochemical properties of the electrocatalysts for a given proton source, which can be done with the help of the relations $k_{\text {cat }} v s . E$ and $k v s . E$ used here.

As a concluding remark, it is to be emphasized that the possibility of tailoring the chemical properties of a $\mathrm{H}_{2}$-production electrocatalyst for specific needs is an advantage that has the molecular approach over the heterogeneous approach.

\section{Acknowledgments}


This work was supported by the Agence Nationale de la Recherche (ANR, BLANC SIMI9/0926-1, “TechBioPhyp”), the Centre National de la Recherche Scientifique (CNRS), and the Université de Bretagne Occidentale (UBO).

\section{References}

[1] M.T.M. Koper, E. Bouwman, Electrochemical hydrogen production: Bridging homogeneous and heterogeneous catalysis, Angew. Chem. Int. Ed., 49 (2010) 3723-3725. [2] M. Rakowski Dubois, D.L. Dubois, Development of molecular electrocatalysts for $\mathrm{CO}_{2}$ reduction and $\mathrm{H}_{2}$ production/oxidation, Acc. Chem. Res., 42 (2009) 1974-1982.

[3] D.G. Nocera, The artificial leaf, Acc. Chem. Res., 45 (2012) 767-776.

[4] U. Koelle, S. Paul, Electrochemical reduction of protonated cyclopentadienylcobalt phosphine complexes, Inorg. Chem., 25 (1986) 2689-2694.

[5] I. Bhugun, D. Lexa, J.-M. Savéant, Homogeneous catalysis of electrochemical hydrogen evolution by iron(0) porphyrins, J. Am. Chem. Soc., 118 (1996) 3982-3983.

[6] J.L. Dempsey, B.S. Brunschwig, J.R. Winkler, H.B. Gray, Hydrogen evolution catalyzed by cobaloximes, Acc. Chem. Res., 42 (2009) 1995-2004.

[7] V. Artero, M. Chavarot-Kerlidou, M. Fontecave, Splitting water with cobalt, Angew. Chem. Int. Ed., 50 (2011) 7238-7266.

[8] P. Du, R. Eisenberg, Catalysts made of earth-abundant elements (Co, Ni, Fe) for water splitting: Recent progress and future challenges, Energy Environ. Sci., 5 (2012) 6012-6021. [9] P.D. Tran, J. Barber, Proton reduction to hydrogen in biological and chemical systems, Phys. Chem. Chem. Phys., 14 (2012) 13772-13784. 
[10] M. Wang, L. Chen, L. Sun, Recent progress in electrochemical hydrogen production with earth-abundant metal complexes as catalysts, Energy Environ. Sci., 5 (2012) 6763-6778. [11] V.S. Thoi, Y. Sun, J.R. Long, C.J. Chang, Complexes of earth-abundant metals for catalytic electrochemical hydrogen generation under aqueous conditions, Chem. Soc. Rev., (2013) http://dx.doi.org/10.1039/C2CS35272A.

[12] D.V. Esposito, S.T. Hunt, A.L. Stottlemyer, K.D. Dobson, B.E. McCandless, R.W. Birkmire, J.G. Chen, Low-cost hydrogen-evolution catalysts based on monolayer platinum on tungsten monocarbide substrates, Angew. Chem. Int. Ed., 49 (2010) 9859-9862.

[13] D.J. Evans, C.J. Pickett, Chemistry and the hydrogenases, Chem. Soc. Rev., 32 (2003) 268-275.

[14] J.F. Capon, F. Gloaguen, P. Schollhammer, J. Talarmin, Catalysis of the electrochemical h2 evolution by di-iron sub-site models, Coord. Chem. Rev., 249 (2005) 1664-1676.

[15] C. Tard, X. Liu, S.K. Ibrahim, M. Bruschi, L.D. Gioia, S.C. Davies, X. Yang, L.-S.

Wang, G. Sawers, C.J. Pickett, Synthesis of the h-cluster framework of iron-only hydrogenase, Nature, 433 (2005) 610-613.

[16] F. Gloaguen, T.B. Rauchfuss, Small molecule mimics of hydrogenases: Hydrides and redox, Chem. Soc. Rev., 38 (2009) 100-108.

[17] C. Tard, C.J. Pickett, Structural and functional analogues of the active sites of the [Fe]-, [NiFe]-, and [FeFe]-hydrogenases, Chem. Rev., 109 (2009) 2245-2274.

[18] B.E. Barton, M.T. Olsen, T.B. Rauchfuss, Artificial hydrogenases, Curr. Opin. Biotechnol., 21 (2010) 292-297.

[19] F. Gloaguen, J.D. Lawrence, T.B. Rauchfuss, Biomimetic hydrogen evolution catalyzed by an iron carbonyl thiolate, J. Am. Chem. Soc., 123 (2001) 9476-9477. 
[20] D. Chong, I.P. Georgakaki, R. Mejia-Rodriguez, J. Sanabria-Chinchilla, M.P. Soriaga, M.Y. Darensbourg, Electrocatalysis of hydrogen production by active site analogues of the iron hydrogenase enzyme: Structure/function relationships, Dalton Trans., (2003) 4158-4163. [21] G.A.N. Felton, C.A. Mebi, B.J. Petro, A.K. Vannucci, D.H. Evans, R.S. Glass, D.L. Lichtenberger, Review of electrochemical studies of complexes containing the $\mathrm{Fe}_{2} \mathrm{~S}_{2}$ core characteristic of [FeFe]-hydrogenases including catalysis by these complexes of the reduction of acids to form dihydrogen, J. Organomet. Chem., 694 (2009) 2681-2699.

[22] F. Quentel, G. Passard, F. Gloaguen, Electrochemical hydrogen production in aqueous micellar solution by a diiron benzenedithiolate complex relevant to [FeFe] hydrogenases, Energy Environ. Sci., 5 (2012) 7757-7761.

[23] F. Quentel, G. Passard, F. Gloaguen, A binuclear iron-thiolate catalyst for electrochemical hydrogen production in aqueous micellar solution, Chem. Eur. J., 18 (2012) 13473-13479.

[24] X. Li, M. Wang, L. Chen, X. Wang, J. Dong, L. Sun, Photocatalytic water reduction and study of the formation of $\mathrm{Fe}^{\mathrm{I}} \mathrm{Fe}^{0}$ species in diiron catalyst sytems, ChemSusChem, 5 (2012) 913-919.

[25] F. Wang, W.-G. Wang, H.-Y. Wang, G. Si, C.-H. Tung, L.-Z. Wu, Artificial photosynthetic systems based on [FeFe]-hydrogenase mimics: The road to high efficiency for light-driven hydrogen evolution, ACS Catal., 2 (2012) 407-416.

[26] J.F. Capon, F. Gloaguen, F.Y. Pétillon, P. Schollhammer, J. Talarmin, Electron and proton transfers at diiron dithiolate sites relevant to the catalysis of proton reduction by the [FeFe]-hydrogenases, Coord. Chem. Rev., 253 (2009) 1476-1494.

[27] J.F. Capon, F. Gloaguen, P. Schollhammer, J. Talarmin, Electrochemical proton reduction by thiolate-bridged hexacarbonyldiiron clusters, J. Electroanal. Chem., 566 (2004) $241-247$ 
[28] J.F. Capon, F. Gloaguen, P. Schollhammer, J. Talarmin, Activation of proton by the twoelectron reduction of a di-iron organometallic complex, J. Electroanal. Chem., 595 (2006) 4752.

[29] F. Gloaguen, D. Morvan, J.F. Capon, P. Schollhammer, J. Talarmin, Electrochemical proton reduction at mild potentials by monosubstituted diiron organometallic complexes bearing a benzenedithiolate bridge, J. Electroanal. Chem., 603 (2007) 15-20.

[30] K. Charreteur, M. Kdider, J.F. Capon, F. Gloaguen, F.Y. Pétillon, P. Schollhammer, J. Talarmin, Effect of electron-withdrawing dithiolate bridge on the electron-transfer steps in diiron molecules related to $[2 \mathrm{Fe}]_{\mathrm{H}}$ subsite of the [FeFe]-hydrogenases, Inorg. Chem., 49 (2010) 2496-2501.

[31] P.Y. Orain, J.F. Capon, F. Gloaguen, P. Schollhammer, J. Talarmin, Tuning of electron transfer in diiron azo-bridged complexes relevant to hydrogenases, Int. J. Hydrogen Energy, 35 (2010) 10797-10802.

[32] L. Chen, M. Wang, F. Gloaguen, D. Zheng, P. Zhang, L. Sun, Multielectron-transfer templates via consecutive two-electron transformations: Iron-sulfur complexes relevant to biological enzymes, Chem. Eur. J., 18 (2012) 13968-13973.

[33] G.A.N. Felton, A.K. Vannucci, J. Chen, L.T. Lockett, N. Okumura, B.J. Petro, U.I. Zakai, D.H. Evans, R.S. Glass, D.L. Lichtenberger, Hydrogen generation from weak acids: Electrochemical and computational studies of a diiron hydrogenase mimic, J. Am. Chem. Soc., 129 (2007) 12521-12530.

[34] D. Streich, Y. Astuti, M. Orlandi, L. Schwartz, R. Lomoth, L. Hammarström, S. Ott, High-turnover photochemical hydrogen production catalyzed by a model complex of the [FeFe]-hydrogenase active site, Chem. Eur. J., 16 (2010) 60-63. 
[35] A.K. Vannucci, S. Wang, G.S. Nichol, D.L. Lichtenberger, D.H. Evans, R.S. Glass, Electronic and geometric effects of phosphatriazaadamantane ligands on the catalytic activity of an [FeFe] hydrogenase inspired complex, Dalton Trans., 39 (2010) 3050-3056.

[36] B. Kumar, M. Beyler, C.P. Kubiak, S. Ott, Photoelectrochemical hydrogen generation by an $[\mathrm{FeFe}]$ hydrogenase active site mimic at a p-type silicon/molecular electrocatalyst junction, Chem. Eur. J., 18 (2012) 1295-1298.

[37] Y.-C. Liu, T.-H. Yen, Y.-J. Tseng, C.-H. Hu, G.-H. Lee, M.-H. Chiang, Electron delocalization from the fullerene attachment to the diiron core within the active-site mimics of [FeFe]hydrogenase, Inorg. Chem., 51 (2012) 5997-5999.

[38] D. Morvan, J.F. Capon, F. Gloaguen, P. Schollhammer, J. Talarmin, Electrochemical synthesis of mono- and disubstituted diiron dithiolate complexes as models for the active site of iron-only hydrogenases, Eur. J. Inorg. Chem., (2007) 5062-5068.

[39] G.A.N. Felton, B.J. Petro, R.S. Glass, D.L. Lichtenberger, D.H. Evans, One- to twoelectron reduction of an [FeFe]-hydrogenase active site mimic: The critical role of fluxionality of the [2Fe2S] core, J. Am. Chem. Soc., 131 (2009) 11290-11291. [40] V. Fourmond, P.-A. Jacques, M. Fontecave, V. Artero, H2 evolution and molecular electrocatalysts: Determination of overpotentials and effect of homoconjugation, Inorg. Chem., 49 (2010) 10338-10347.

[41] G.A.N. Felton, R.S. Glass, D.L. Lichtenberger, D.H. Evans, Iron-only hydrogenase mimics. Thermodynamic aspects of the use of electrochemistry to evaluate catalytic efficiency for hydrogen generation, Inorg. Chem., 45 (2006) 9181-9184.

[42] J.A. Widegren, R.G. Finke, A review of the problem of distinguishing true homogeneous catalysis from soluble or other metal-particle heterogeneous catalysis under reducing conditions, J. Mol. Catal. A: Chem., 198 (2003) 317-341. 
[43] V. Artero, M. Fontecave, Solar fuels generation and molecular systems: Is it homogeneous or heterogeneous catalysis?, Chem. Soc. Rev., (2013).

[44] R.S. Nicholson, I. Shain, Theory of stationary electrode polarography. Single scan and cyclic methods applied to reversible, irreversible, and kinetic systems, Anal. Chem., 36 (1964) 706-723.

[45] A.J. Sathrum, C.P. Kubiak, Kinetics and limiting current densities of homogeneous and heterogeneous electrocatalysts, J. Phys. Chem. Lett., 2 (2011) 2372-2379.

[46] M.L. Helm, M.P. Stewart, R.M. Bullock, M.R. DuBois, D.L. DuBois, A synthetic nickel electrocatalyst with a turnover frequency above $100,000 \mathrm{~s}^{-1}$ for $\mathrm{H}_{2}$ production, Science, 333 (2011) 863-866.

[47] M.J. Rose, H.B. Gray, J.R. Winkler, Hydrogen generation catalyzed by fluorinated diglyoxim-iron complexes at low overpotentials, J. Am. Chem. Soc., 134 (2012) 8310-8313. [48] V.S. Thoi, H.I. Karunadasa, Y. Surendranath, J.R. Long, C.J. Chang, Electrochemical generation of hydrogen from acetic acid using a molecular molybdenum-oxo catalyst, Energy Environ. Sci., 5 (2012) 7762-7770.

[49] J.M. Savéant, Elements of molecular and biomolecular electrochemistry: An electrochemical approach to electron transfer chemistry, Wiley-Interscience, New York, 2006. [50] C. Costentin, S. Drouet, M. Robert, J.-M. Savéant, Turnover numbers, turnover frequencies, and overpotential in molecular catalysis of electrochemical reactions. Cyclic voltammetry and preparative-scale electrolysis, J. Am. Chem. Soc., 134 (2012) 11235-11242. [51] S. Kozuch, J.M.L. Martin, "Turning over" Definitions in catalytic cycles, ACS Catal., 2 (2012) 2787-2794. 


\section{Schemes}

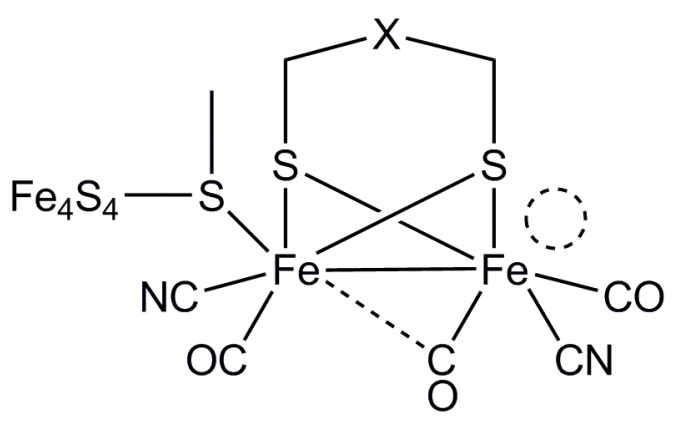

$\mathrm{X}=\mathrm{CH}_{2}$ or $\mathrm{NH}$

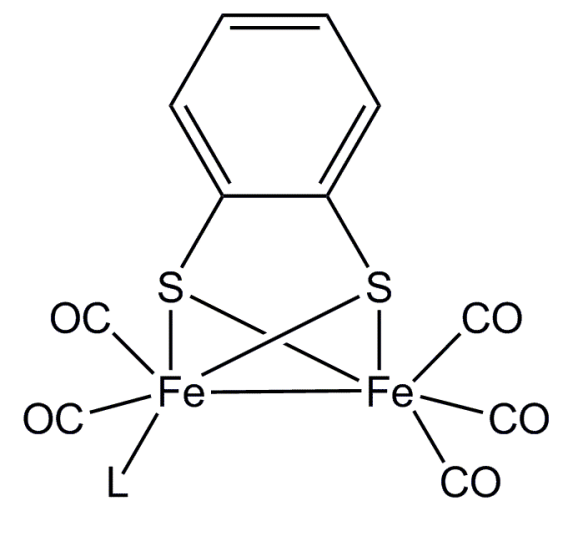

1: $L=C O ; 2: L=P(O M e)_{3}$

Scheme 1. Structure of the iron-iron hydrogenase active site (left) and compounds $\mathbf{1}$ and $\mathbf{2}$ (right).

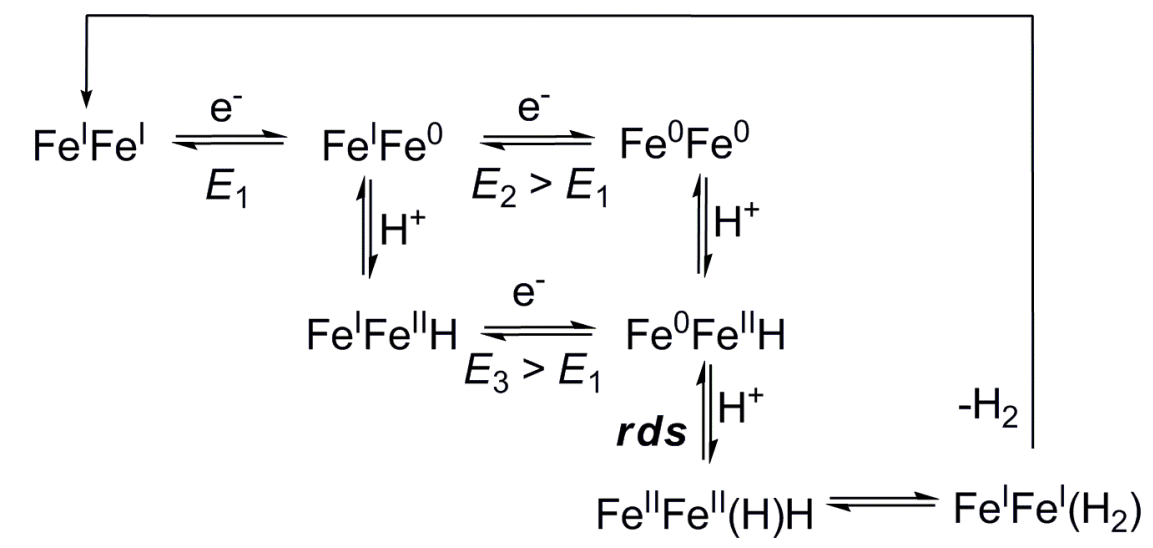

Scheme 2. Proposed mechanism for the electrocatalytic reduction of $p$-toluenesulfonic acid by compound $\mathbf{2}$ in acetonitrile. 
Figures [to be reproduced in color on the Web (free of charge) and in black-and-white in print]
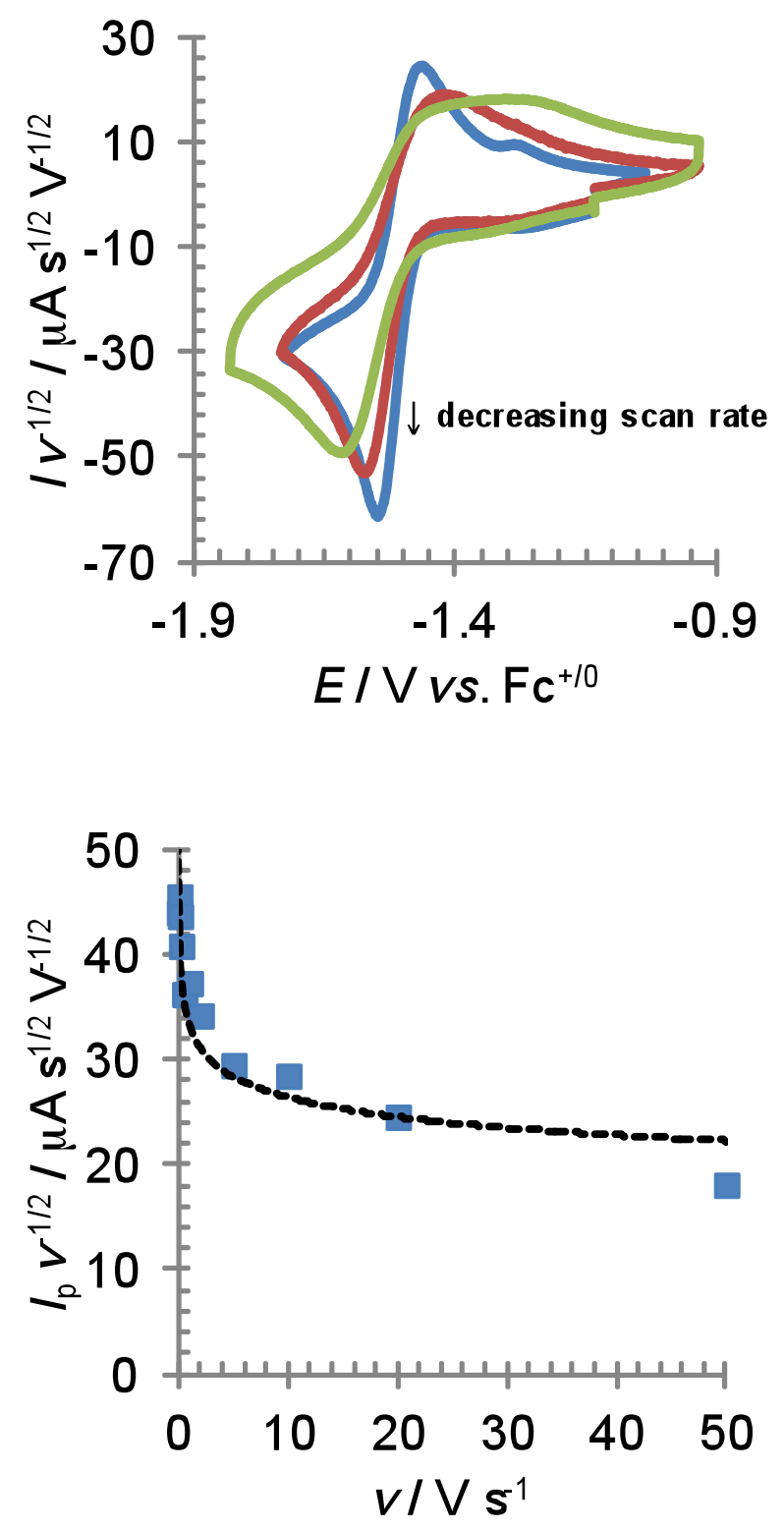

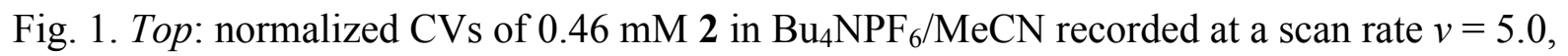
0.5 and $0.05 \mathrm{~V} \mathrm{~s}^{-1}$, respectively. Bottom: plot of the normalized peak current $I_{\mathrm{p}} / v^{1 / 2}$ as a function of $v$ showing the transition from a one- to a two electron-process as the scan rate is slowed down. 

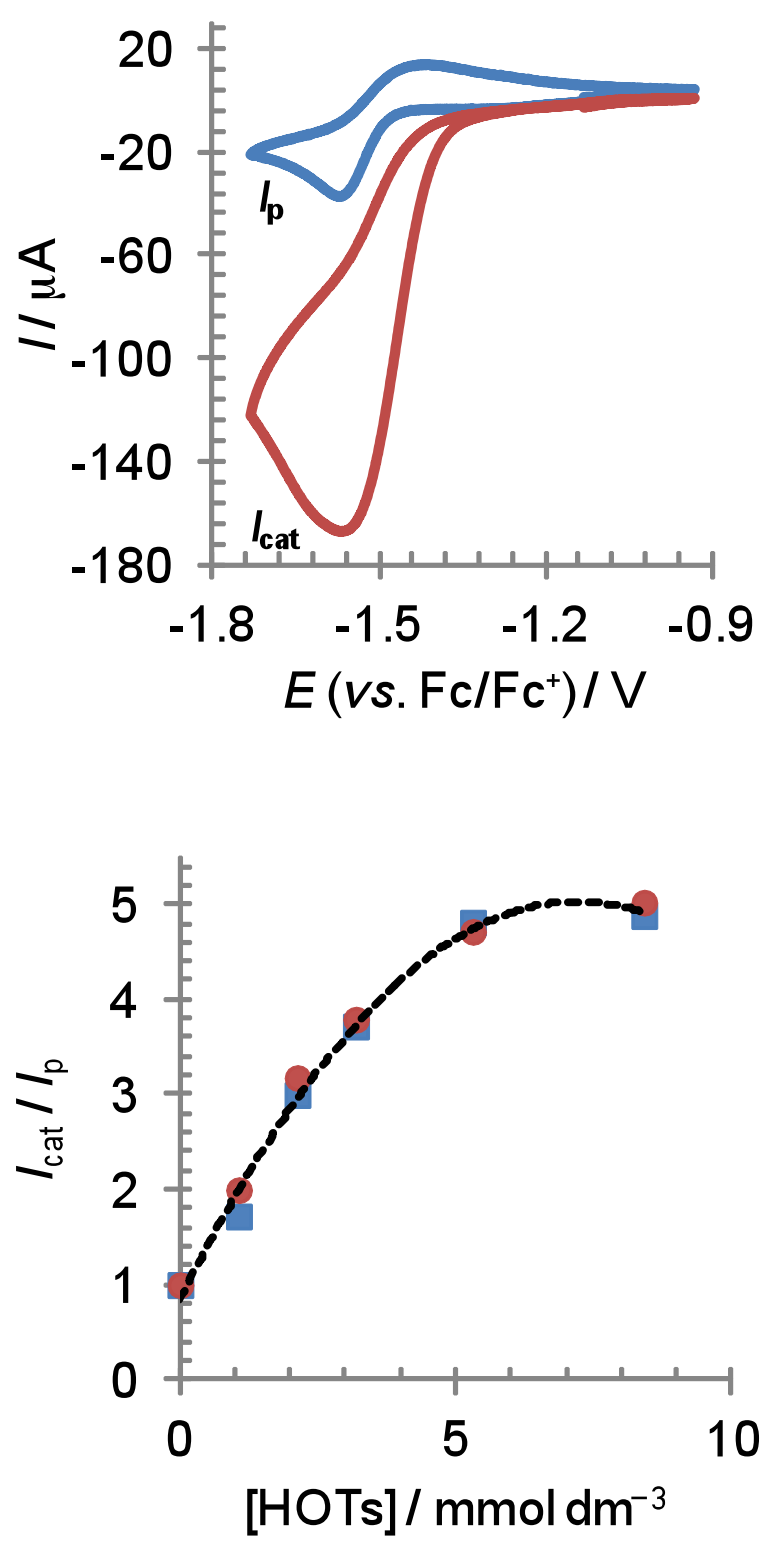

Fig. 2. Top: $\mathrm{CV}$ at $0.5 \mathrm{~V} \mathrm{~s}^{-1}$ of $0.46 \mathrm{mM} 2$ in $\mathrm{Bu}_{4} \mathrm{NPF}_{6} / \mathrm{MeCN}$ before and after addition of 5.3 mM HOTs. Bottom: plot of the current enhancement $I_{\text {cat }} / I_{\mathrm{p}}$ as function of the concentration of HOTs at a scan rate of $0.5 \mathrm{~V} \mathrm{~s}^{-1}$ (squares) and $5 \mathrm{~V} \mathrm{~s}^{-1}$ (circles), respectively. 

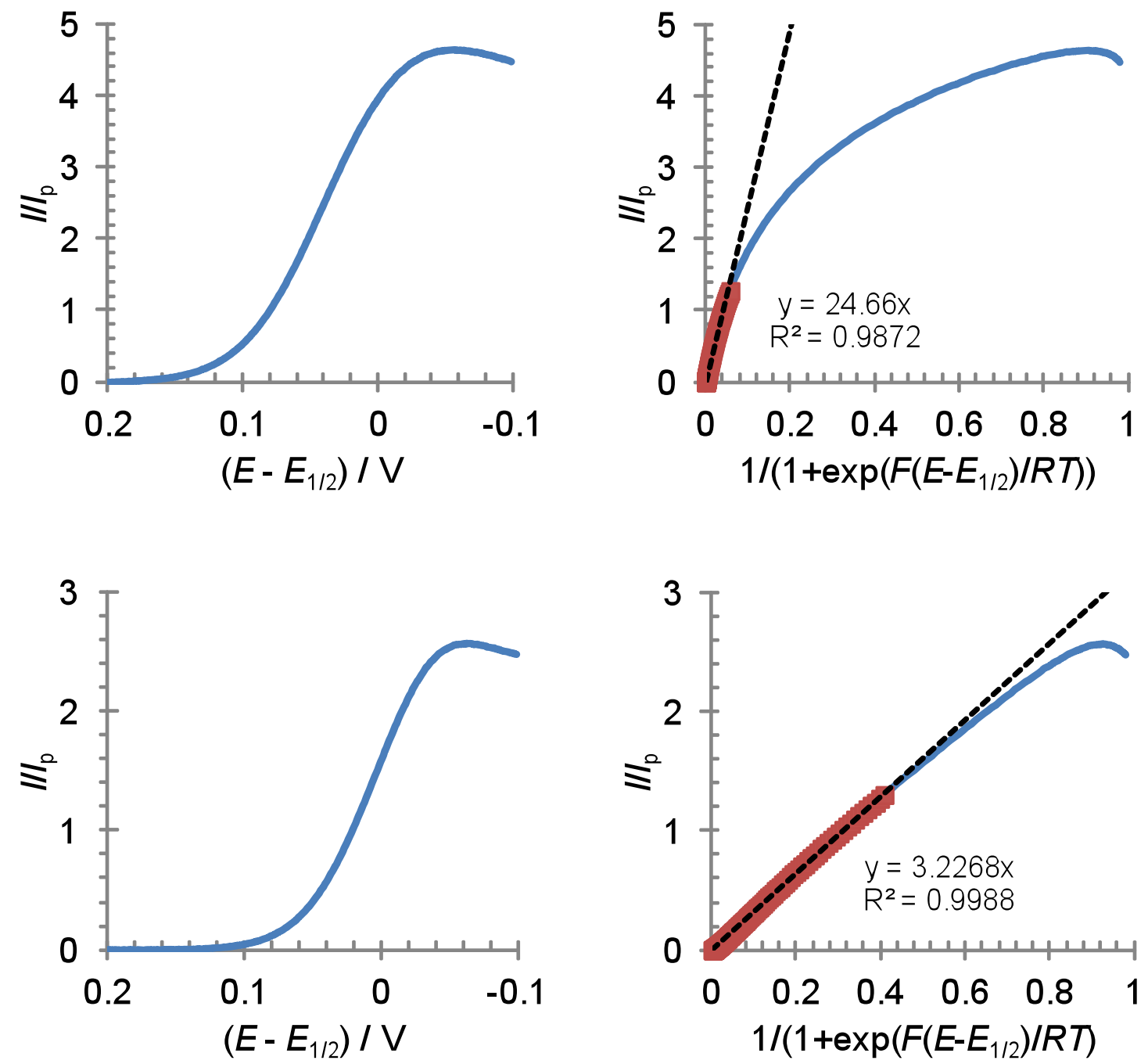

Fig. 3. Left: background-corrected electrocatalytic responses of $\mathbf{2}$ (top) and $\mathbf{1}$ (bottom) in the presence of 12 molar equiv. of HOTs derived from CVs recorded at $0.5 \mathrm{~V} \mathrm{~s}^{-1}$. Right: foot-ofthe-wave analyses. Linear fits (dotted line) to the data show that the electrocatalytic responses deviate from ideal behavior at $I / I_{\mathrm{p}}>1.3$. 


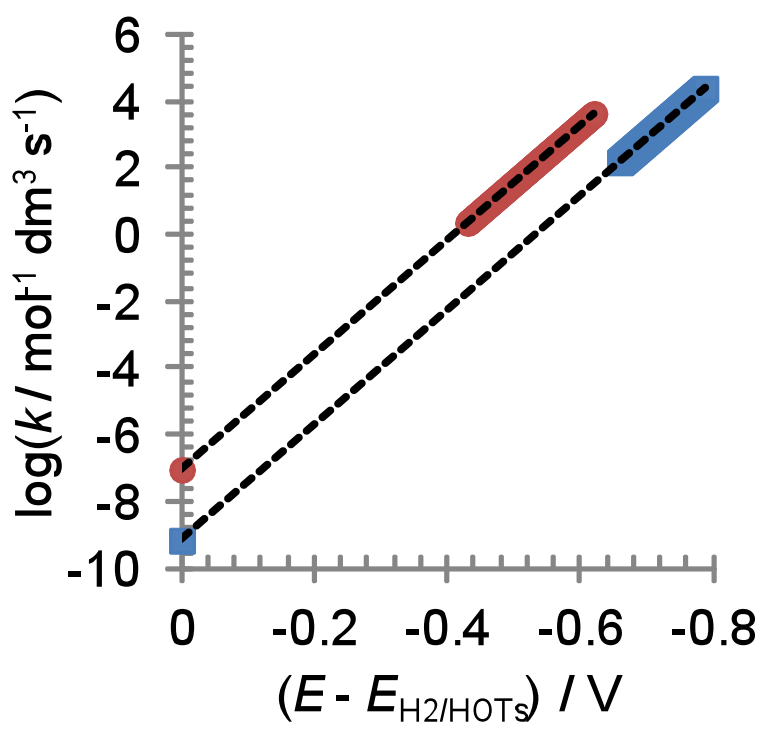

Fig. 4. Plots of the second-order rate constants $k$ as a function of the driving force $E-E_{\mathrm{H} 2 / \mathrm{HOTs}}$ for $\mathbf{2}$ (squares) and $\mathbf{1}$ (circles) derived from the foot-of-the analyses of the electrocatalytic responses shown in Fig. 3. 